\title{
Fossil cetaceans from Duinefontein (Koeberg) an early Pliocene site on the southwestern Cape, South Africa
}

\author{
Romala Govender
}

\begin{abstract}
Koeberg is a Zanclean, subsurface locality on the west coast of South Africa, which was unearthed during the excavations of the Koeberg Power Station foundations. Mysticetes and odontocetes have been identified from this locality ca. $12 \mathrm{~m}$ below the surface. The preservational nature prevents species level identification in some instances. The balaenopterids are represented by specimens assigned to 'Balaenoptera' borealina, Diunatans sp. 1 and Fragilicetus sp. while other specimens are only identified as balaenopterids. The odontocetes have been referred to Odontoceti indet. (possibly delphinids), a beaked whale (cf. Izikoziphius) and a single phocoenid, cf. Australithax. There is undescribed odontocetes most likely physeterids. The balaenopterids and odontocetes suggest a connection of the west coast of South Africa to north Atlantic of Europe and North America, and eastern South Pacific.
\end{abstract}

Romala Govender. Research and Exhibitions, Iziko Museums of South Africa, P. O. Box 61, Cape Town, 8001, South Africa, rgovender@iziko.org.za and Department of Biological Sciences, University of Cape Town, Private Bag X3, Rhodes Gift, 7701, Cape Town, South Africa.

Keywords: cetaceans; balaenopterid; odontocete; Koeberg; Neogene; Pliocene

Submission: 17 April 2016 Acceptance: 24 December 2018

\section{INTRODUCTION}

Onshore Cenozoic deposits are rare along South Africa's west coast, as a result of erosion from the interior during the Cretaceous and Cenozoic (Dingle et al., 1983; Pether et al., 2000; Roberts et al., 2006) as Africa moved northward to collide with Eurasia (Hendey, 1983). Africa was later separated from Eurasia when the Strait of Gibraltar was flooded during the late Miocene transgression (Hendey and Dingle, 1989; Potter and Szatmari, 2009) and was subsequently followed by the early Pliocene transgression (Hendey, 1981).

Thirty-five kilometres north of Cape Town and ca. $90 \mathrm{~km}$ south of Langebaanweg (a Mio-Pliocene site) is the early Pliocene site of Duinefontein (Koeberg). This subsurface locality, discovered in the 1970s when foundations for the Koeberg Power Station were being dug, extends to about 10-12 m

Govender, Romala. 2019. Fossil cetaceans from Duinefontein (Koeberg) an early Pliocene site on the southwestern Cape, South Africa. Palaeontologia Electronica 22.1.6A 1-21. https://doi.org/10.26879/673

palaeo-electronica.org/content/2019/2398-koeberg-early-pliocene-cetacea

Copyright: February 2019 Palaeontological Association.

This is an open access article distributed under the terms of the Creative Commons Attribution License, which permits unrestricted use, distribution, and reproduction in any medium, provided the original author and source are credited.

creativecommons.org/licenses/by/4.0/ 
below sea level and contained a rich fossil marine fauna (e.g., sharks, cetaceans, seals and teleost fish [vertebrae, teeth, scales and spines]) (Rogers, 2006; Table 1). It also produced other fossil taxa including ungulate, lagomorph, snake, turtle and penguins (Rogers, 1979; Table 1). The pinnipeds are represented by a single femur that has been assigned to Arctocephalus sp. (Avery and Klein, 2011) and other fragmentary remains (personal observations).

This study focuses on the cetaceans from Duinefontein (Koeberg) consisting of mysticetes and odontocetes. A comparison with Langebaanweg to the north will give further insight into the cetacean community along the South African west coast during the late Miocene to early Pliocene.

\section{GEOLOGICAL SETTING}

Just inland of the west coast of South Africa is the Zanclean (early Pliocene) locality of Duinefon- tein (Koeberg) (below the Koeberg Power Station) on the farm Duynefontyne 34 (Rogers, 1979, 1980, 2006) (Figure 1.1). Rogers $(1980,1982)$ recognised marginal deposits that were non-calcareous and had phosphatised shell fragments at Melkbosstrand. He named it the Duynefontyn Member of the Varswater Formation (Rogers, 1979). He also suggested that it was equivalent to the Muishond Fontein Peletal Phosphorite member (MPPM) from Langebaanweg (Rogers, 1982). Roberts (2006) found similarities to the MPPM type area in thickness, size grade, presence of phosphatised shell fragments (black rather than amber) and palaeontology therefore he included it in Muishond Fontein Peletal Phosphorite member giving the Koeberg deposit a Zanclean age (early Pliocene). A relatively large marine avifauna exists at Duinefontein, 16 or 17 species, (Olson, 1985a; Table 1). Of these, 10 or 12 species are shared with Langebaanweg from the Langeberg Quartz

TABLE 1. Faunal list for Koeberg (Duinefontein) complied from Cenozoic Palaeontology catalogue books and Olson, 1985b compared with Langebaanweg.

\begin{tabular}{|c|c|c|c|}
\hline Taxon & Common name & Koeberg & $\begin{array}{l}\text { Langebaanweg } \\
\text { (LQSM, MPPM) }\end{array}$ \\
\hline 'Nucleornis' insolitus & penguin & $x$ & $x$ \\
\hline 'Dege' hendeyi & penguin & $x$ & $x$ \\
\hline '?Palaespheniscus' huxleyorum & penguin & $x$ & $x$ \\
\hline Inguza predemersus & penguin & $x$ & $x$ \\
\hline Oceanites sp. & Storm-petrel & $x$ & - \\
\hline Fulmarinae gen. et sp. indet. & petrel & $x$ & $?$ \\
\hline Pachyptila salax & petrel & $x$ & $x$ \\
\hline Pachyptila species B & petrel & $x$ & - \\
\hline Pachyptila species C & petrel & $x$ & - \\
\hline Procellaria sp. & Petrel & $x$ & - \\
\hline Calonectris sp. & shearwater & $\mathrm{x}$ & - \\
\hline Puffinus (Puffinus) species A & Puffin & $x$ & - \\
\hline Puffinus (Puffinus) species B & Puffin & $x$ & - \\
\hline Puffinus (Puffinus) species C & Puffin & $x$ & - \\
\hline Sula sp. & booby & $x$ & $x$ \\
\hline Phalacrocorax sp. & cormorant & $x$ & $x$ \\
\hline Phalacrocorax cf (Microcarbo) sp. & Small cormorant & $?$ & $x$ \\
\hline Medium indeterminate Procellariidae & Petrel, shearwater, prion & $x$ & $x$ \\
\hline Phasianidae & $\begin{array}{l}\text { includes pheasants, partridges, jungle fowl, } \\
\text { chickens, Old World quail, and peafowl }\end{array}$ & $x$ & $x$ \\
\hline Francolinus sp. & francolin & $x$ & $x$ \\
\hline Carcharocles megalodon & Megalodon & $x$ & $x$ \\
\hline Carcharodon carcharias & White shark & $x$ & $x$ \\
\hline Carcharias taurus & Ragged tooth shark & $x$ & $x$ \\
\hline
\end{tabular}


Sand (LQSM) and MPPM (Table 1; Olson, 1983, $1985 a, b)$ thus confirming its Zanclean (early Pliocene) age. During the transgressive phases of the late Miocene and early Pliocene, this deposit was most likely off shore (Rogers, 1979; Olson, 1985a).

This part of the MPPM is a prograding sequence that was initiated by the Zanclean (early Pliocene) transgression as it moved across the Malmesbury bedrock leaving no evidence of a transgression complex (Rogers, 1979, 1980). The fossils preserved in this member are ca $8.5 \mathrm{~m}$ below sea level, and the member is divided into five beds (Rogers, 1979, 1980, 1982) (Figure 1.2). The basal gravel bed is located above the bedrock (Rogers, 2006) and is interpreted as a high-energy shingle beach (Rogers, 2006 and references therein).

At the base of the MPPM at Koeberg there is a fine sand bed $(1.8 \mathrm{~m})$, that is slightly bioturbated, with horizontal laminae and phosphate, deposited by fast flowing water in upper flow regime conditions (Rogers, 2006; references therein). It contains sand prawn burrows (Callianassa) and was interpreted as a lower intertidal sandflat (references in Rogers, 2006). The most important bed is the $0.1 \mathrm{~m}$ shark tooth bed interpreted as a tsunamite deposit (Rogers, 2006) with a rich fossil shark, teleost fish, marine mammal and bird fauna preserved (Table 1). The thickest bed of the MPPM at Koeberg is the upper completely bioturbated sand bed $(9.2 \mathrm{~m}$ ) (Rogers, 1979, 2006). It is interpreted as an upper-intertidal sandflat similar to those found in the Holocene Langebaan lagoon while the channel is interpreted as a meandering subtidal channel (Rogers, 2006, references therein). The rich fossil material includes terrestrial mammals and reptiles (Table 1; Rogers, 1979, 1980) while the terrestrial pollen is too sparse to identify (Rogers, 1979, 1980).

TABLE 1 (continued).

\begin{tabular}{|c|c|c|c|}
\hline Taxon & Common name & Koeberg & $\begin{array}{l}\text { Langebaanweg } \\
\text { (LQSM, MPPM) }\end{array}$ \\
\hline Alopias vulpinus & Thresher shark & $x$ & - \\
\hline Isurus oxyrhynchus & Mako shark & $x$ & $x$ \\
\hline Sphyrna zygaena & Smooth hammerhead & $x$ & - \\
\hline Pristidae & Saw fish & $x$ & $x$ \\
\hline Sparidae & Mussel cracker (personal observation) & $x$ & $x$ \\
\hline Myliobatidae & Eagle ray & $x$ & $x$ \\
\hline Balistidae & Trigger fish & $x$ & - \\
\hline Tachysurus & Catfish/barbel & $x$ & $x$ \\
\hline Xiphiidae & Sword fish & $x$ & - \\
\hline Arctocephalu sp. & Cape fur seal & $x$ & - \\
\hline Homiphoca & Phocid seal & $?$ & $x$ \\
\hline Hyaenidae & hyaena & $x$ & $x$ \\
\hline Bathyergidae & molerat & $x$ & $x$ \\
\hline Testudinidae & Tortoise & $x$ & $x$ \\
\hline Ceratotherium & White rhino & $x$ & $\mathrm{x}$ \\
\hline Pelorovis antiquus & Buffalo & $\mathrm{x}$ & - \\
\hline Taurotragus strepsiceros & Eland & $x$ & - \\
\hline Antilopini & Gazelles, springbok, gerenuk, and blackbuck & $x$ & $\mathrm{x}$ \\
\hline Alcelaphini & wildebeest, hartebeest, bonteboks & $x$ & $x$ \\
\hline Antidorcas sp. & springbok & $x$ & - \\
\hline Redunca sp. & reedbok & $x$ & - \\
\hline Raphicerus sp. & Grysbok, steenbok, & $\mathrm{x}$ & - \\
\hline Connochaetes sp. & wildebeest & $x$ & - \\
\hline Hipparion & equid & $x$ & $x$ \\
\hline Lagomorpha & hare & $x$ & $x$ \\
\hline
\end{tabular}



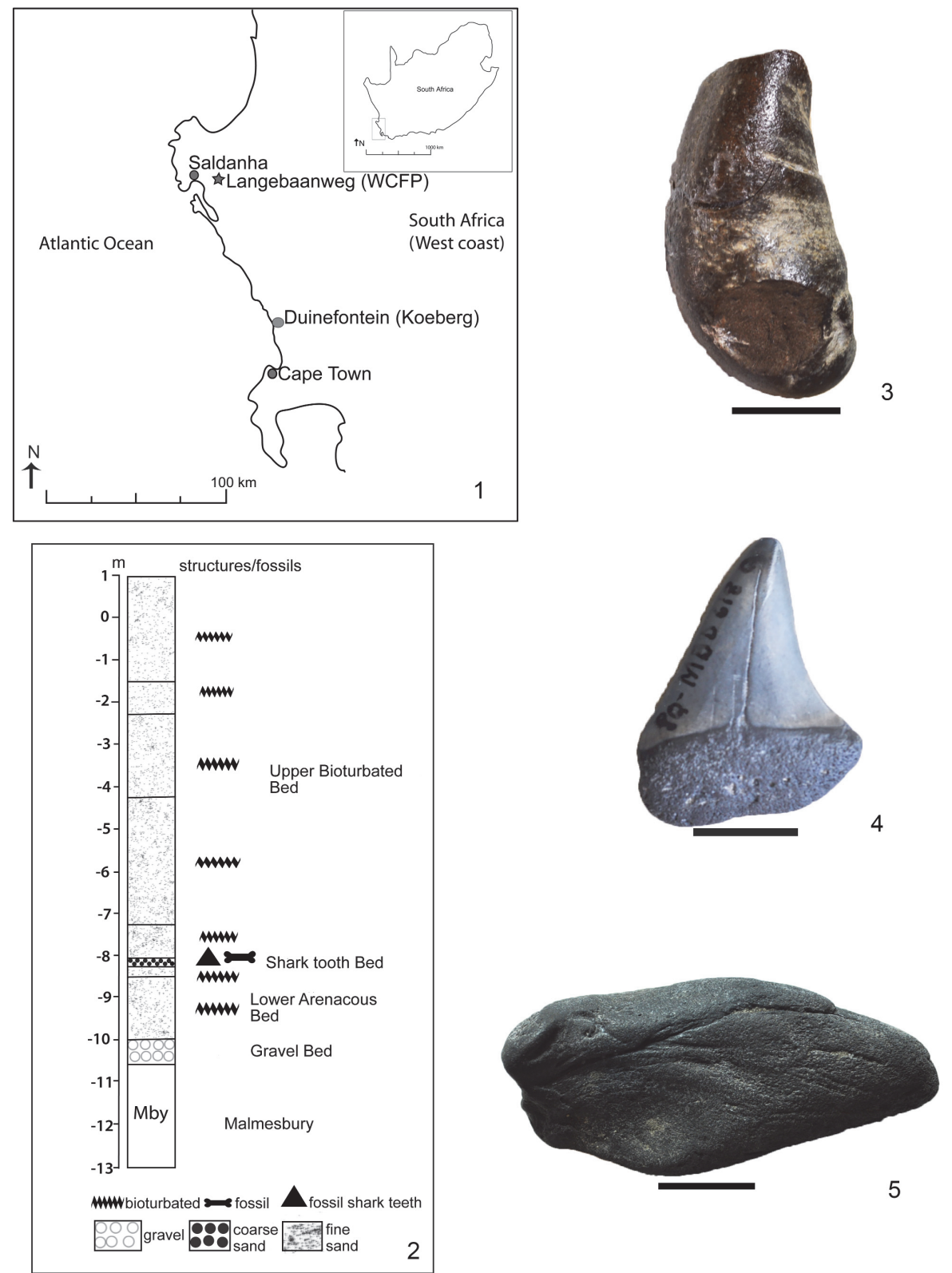

FIGURE 1. 1) Map showing the locality Duinefontein (Koeberg). 2) Stratigraphic section of the Muishond Fontein Peletal Phosphorite Member of the Varswater Formation at Duinefontein (Koeberg) (after Rogers, 1979). 3) polished incomplete tympanic bulla (SAM-PQMBD-1197). scale equals $2 \mathrm{~cm}$. 4) Abraded shark tooth (SAM-PQMBD-618G). scale equals $2 \mathrm{~cm}$. 5) Rolled balaenopterid periotic posterior process. scale equals $2 \mathrm{~cm}$.

\section{PALAEOENVIRONMENT RECONSTRUCTION}

With each successive regression, a barrier spit developed parallel to the coast which absorbed the energy from the wave action characteristic of the west coast open ocean (Rogers, 1979, 1980). Its basal gravel bed formed on the horns of the beach cusps similar to the beach near Milnerton while the slightly bioturbated sand bed formed on the sheltered side of the barrier in a lagoon beach
(Rogers, 1979). The adjacent intertidal mixed flats were dominated by burrowing infauna indicative of a slow sedimentation rate (Rogers, 1979, 1980). After the barrier spit was overtopped by storms and the retreating water scoured the intertidal flats, the shark tooth bed was concentrated into a lag deposit (Rogers, 1979, 1980). The intertidal mixed flats were drained by the subtidal channel (Rogers, 1979). The fossil seabirds suggest that the marine palaeoenvironment was sub-Antarctic (Olson, 

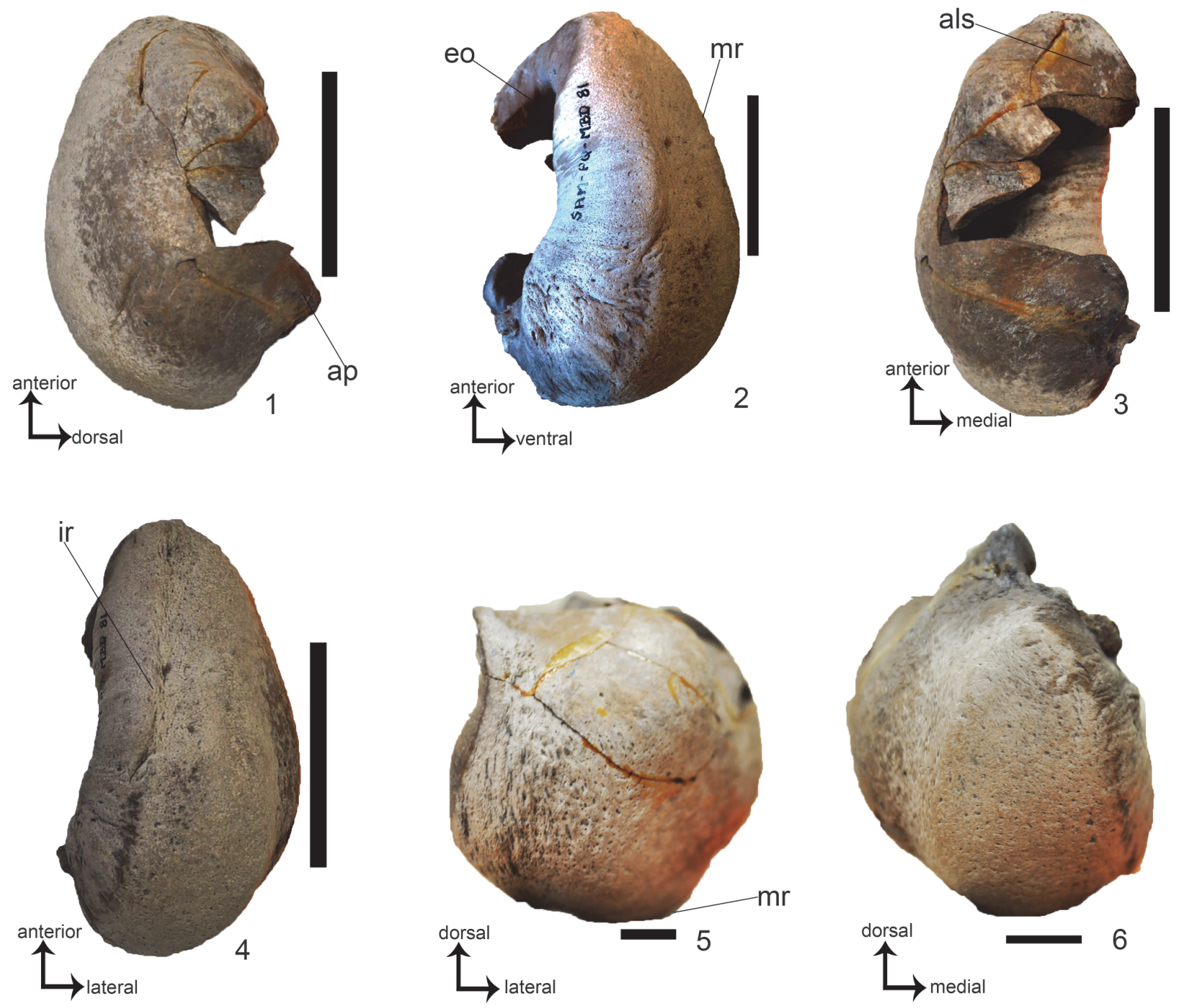

FIGURE 2. Tympanic bulla of 'Balaenoptera' borealina (SAM-PQMBD-81). 1) Lateral view. 2) medial view. 3) ventral view. 4). dorsal view. 5) anterior view. 6) posterior view. scale equals $5 \mathrm{~cm}$.

1983). The presence of entirely pelagic, migrating and non-breeding birds indicates that the area was open to the ocean at times (Olson, 1985a). This would suggest that the depositional environment switched between open beach and lagoon setting during regressive phases (Rogers, 1979).

\section{MATERIALS AND METHODS}

Eleven cetacean fossil specimens (Figures 27) have been included in this study; all specimens are housed at the Iziko South African Museum, Cape Town. The cetacean fossils were recovered during three excavations of the Koeberg Power station foundations, about $35 \mathrm{~km}$ north of Cape Town. They are fragmentary but there are specimens that retain taxonomic information. Vertebrae, teeth, cranial fragments and petrotympanic bones represent both mysticetes and odontocetes. The fossil remains from Duinefontein (Koeberg) are abraded, and some have a polished surface (stage 2; Boessenecker et al., 2014) (Figure 1.3-5). The rich fossil material was recovered from the shark tooth bed (Rogers, 1979, 1982, 2006). The anatomical terms for the odontocetes follows Mead and Fordyce (2009) while the terminology for the mysticete descriptions follows that Boessenecker (2013). The comparative analysis is based on the following references; extant balaenopterids (Ekdale et al., 2011), cf. Plesiobalaenoptera (Govender et al., 2016), Plesiobalaenoptera (Bisconti, 2010), Incakujira (Marx and Kohno, 2016), Fragilicetus (Bisconti and Bosselaers, 2016), Parietobalaena (Kellogg, 1969a), Pelocetus (Kellogg, 1969a) Uranocetus (Steeman, 2009), 'Balaenoptera' borealina (Van Beneden, 1882; Whitmore and Kalten- 

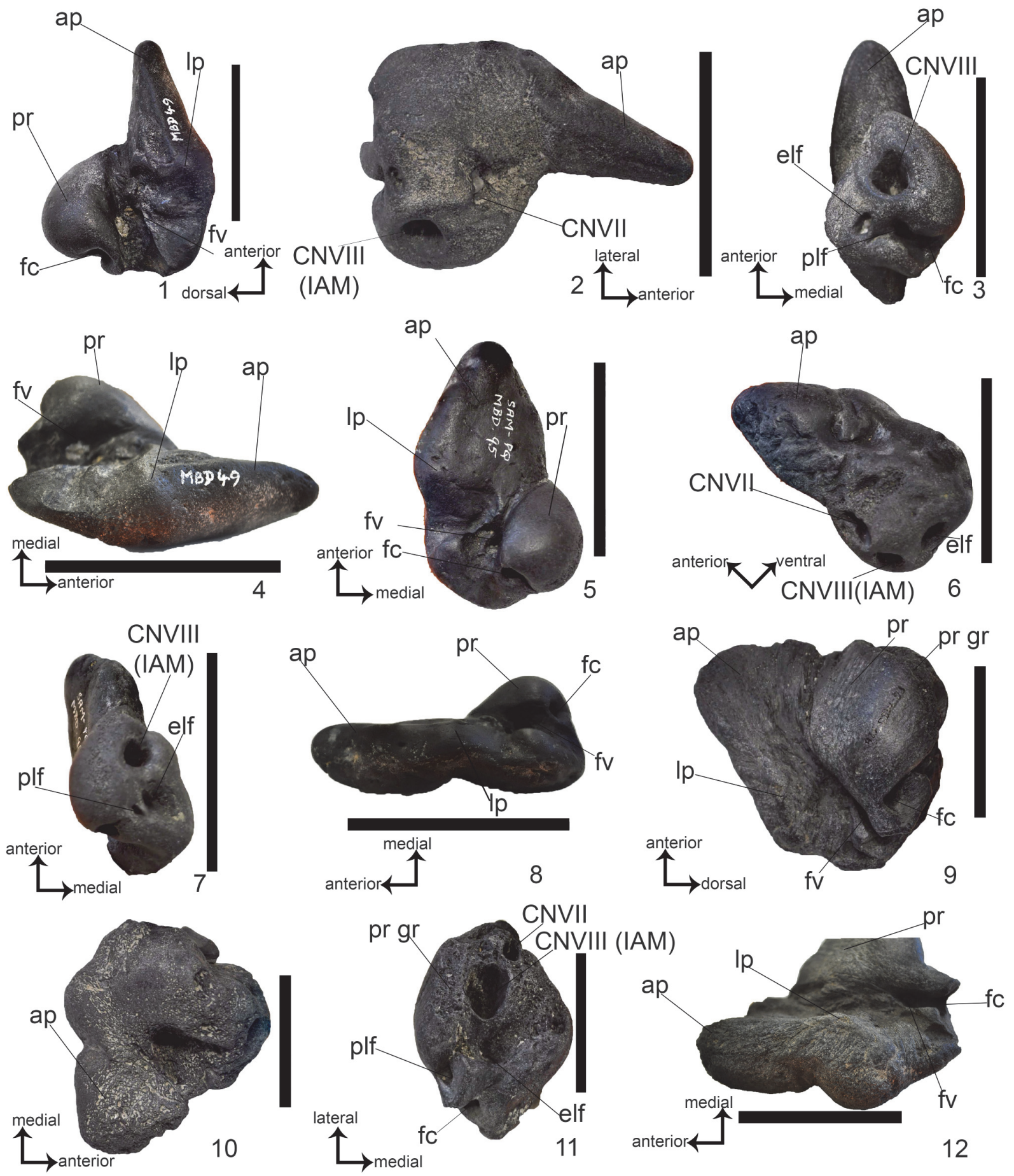

FIGURE 3. Periotic of Fragilicetus sp. (SAM-PQMBD-49). 1) medial view. 2) lateral view. 3) dorsal view. 4) ventral view. Periotic of Diunatans sp. 1 (SAM-PQMBD-95). 5) medial view. 6) lateral view. 7) dorsal view. 8) ventral view. Periotic of 'Balaenoptera' borealina (SAM-PQMBD-526). 9) medial view. 10) lateral view. 11) dorsal view. 12) ventral view. scale equals $5 \mathrm{~cm}$ 

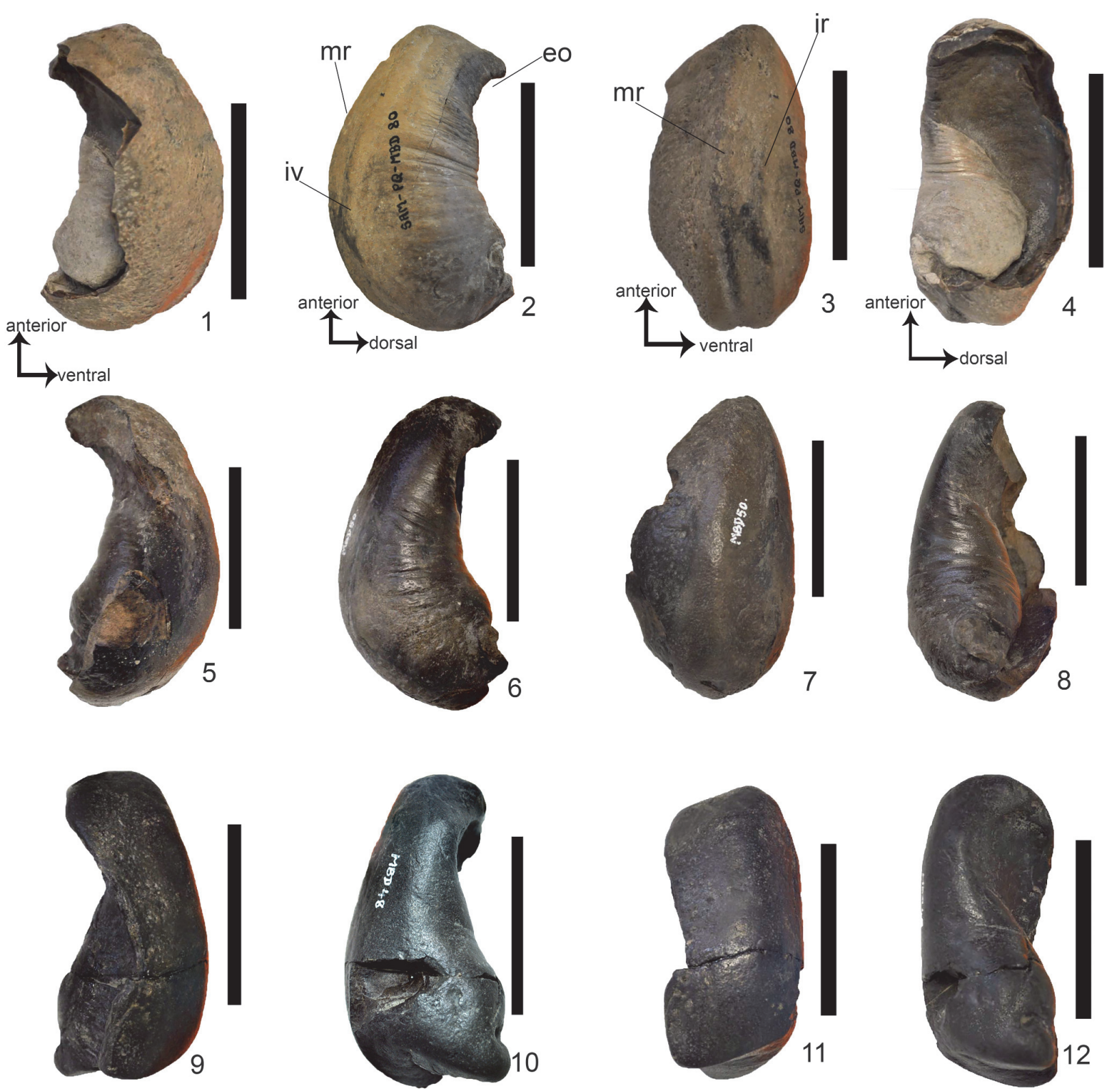

FIGURE 4. Tympanic bulla of Balaenoptera indet. (SAM-PQMBD-80). 1) lateral view. 2) medial view. 3) ventral view. 4) dorsal view. Tympanic bulla of Balaenoptera indet. (SAM-PQMBD-50). 5) lateral view. 6) medial view. 7) ventral view. 8) dorsal view. Tympanic bulla of Balaenoptera indet. (SAM-PQMBD-48). 9) lateral view. 10) medial view. 11) ventral view. 12) dorsal view. scale equals $5 \mathrm{~cm}$.

bach, 2008), Diunatans (Bosselaers and Post, 2010), Diorocetus (Kellogg, 1969a), Thinocetus (Kellogg, 1969b), Piscolithax tedford and Piscolithax boreios (Barnes, 1984), Globicephalinae (Boessenecker et al., 2015), Australithax (Muizon, 1988a), Lomacetus (Muizon, 1988b), Pterophocaena (Murakami et al., 2012), Haborophocoena (Ichishima and Kimura, 2005), Numataphocoena (Ichishima and Kimura, 2000), Phocoena (Gutstein et al., 2014), Semirostrum (Racicot et al., 2014) and Tursiops (Mead and Fordyce, 2009).

\section{Abbreviations}

als = anterolateral shelf, ap = anterior process, $\mathrm{CN}$ $\mathrm{VII}=$ endocranial opening of the facial canal, $\mathrm{cp}=$ conical process, $\mathrm{dpp}=$ dorsal posterior prominence, elf = endolymphatic foramen, eo, Eustachian opening, $\mathrm{fc}=$ fenestra cochleae (Round Window), $\mathrm{fv}=$ fenestra vestibuli (Oval Window), 

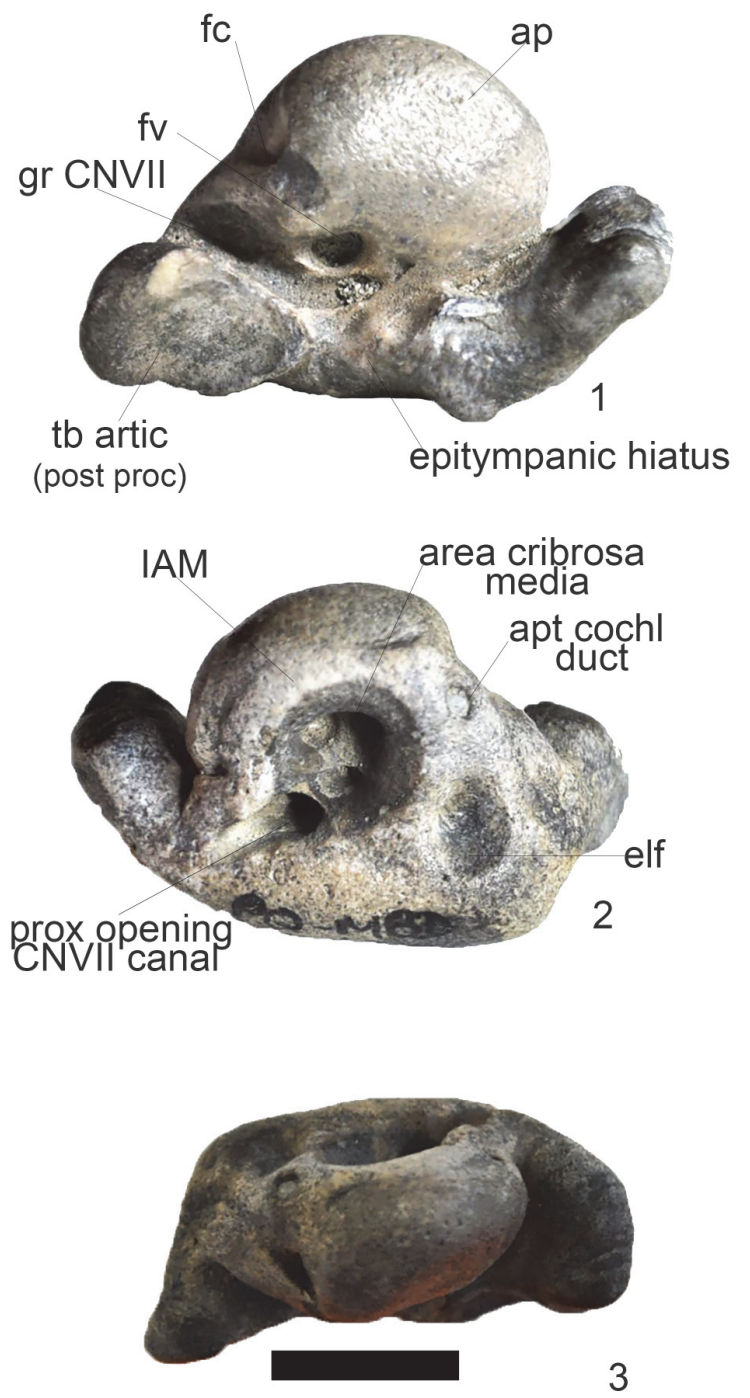

FIGURE 5. Periotic of cf Australithax (SAM-PQMBD363). 1) Ventral view. 2) Dorsal view. 3) Medial view. scale equals $1 \mathrm{~cm}$.

IAM $($ CNVIII) = internal acoustic meatus, ir = involucral ridge, iv = involucrum, $\mathrm{lp}=$ projection of the lateral tuberosity, $\max =$ maxilla, $\mathrm{mf}=$ median furrow $\mathrm{mr}=$ main ridge, $\mathrm{pcc}=$ posterior cochlear crest, plf $=$ perilymphatic foramen, $\mathrm{pc}=$ pars cochlearis, premax $=$ premaxilla, $\mathrm{pp}=$ posterior process, $\mathrm{sm} \mathrm{f}=$ suprameatal fossa, $\mathrm{tc}=$ tympanic cavity, teg tymp = tegmen tympani, $v=$ vomer.

Institutional abbreviation. SAM-PQMBD-South African Museum Melkbos Duinefontein; SAM-PQLSouth African Museum Quaternary Palaeontology Langebaanweg. SAM-MBK-ZM-South African Museum Marine Biology, Zoology Mammals. IRSNB- Institut Royal des Sciences Naturelles de Belgique.

\section{DESCRIPTION OF SELECTED FOSSIL CETACEANS FROM DUINEFONTEIN}

The descriptions are based on relatively wellpreserved specimens, which allow taxonomic identification. Taphonomic damage to some of the bones identified as shark tooth marks is discussed elsewhere (Govender, 2015). To date no terrestrial carnivore damage has been identified (see Cione et al., 2010). To identify these specimens, they have been compared with other similar aged assemblages and specimens in the literature, at the Royal Belgian Institute of Natural Sciences and at Iziko South African Museum.

BALAENOPTERIDAE Gray, 1864

BALAENOPTERA Lacepede, 1804

'Balaenoptera' borealina Van Beneden, 1880

Figure 2.1-6; 3.9-12

Referred material. SAM-PQMBD-81 - laterally incomplete left tympanic bulla and the sigmoid process is missing (Figure 2.1-6; Table 2). SAMPQMBD-526 - right periotic. The posterior process is missing (Figure 3.9-12; Table 3).

Locality and horizon. SAM-PQMBD-81 - Duinefontein, Koeberg A, Power station, pickups - reactor site. SAM-PQMBD-526 - Duinefontein, Koeberg $A$, Reactor site dumps.

Age. Zanclean (early Pliocene).

Diagnosis. Synapomorphies shared with balaenopterids: reniform shape, rounded anterolateral border. Synapomorphies shared with 'Balaenoptera' borealina: the conical process is tall and triangular; the lateral surface is sinusoidal; the anteroventral corner is angular; ovoid Eustachian opening; the main ridge is parallel to the involucral ridge and ventral keel present. It differs from ' $B$.' borealina in that it falls outside the size range of 100-123 mm for the Lee Creek specimens and 111 $\mathrm{mm}$ and $114 \mathrm{~mm}$ for the European specimens (Whitmore and Kaltenbach, 2008).

A comparison with the ' $B$.' borealina from Belgium, showed that SAM-PQMBD-81 most closely resembles IRSNB M 777. They share the following synapomorphies: wide, triangular conical process; dorsoventrally narrow; longer anterior lobe; posterior lobe less expanded; ventral keel; similarly, convex lateral surface and slightly concave involucrum surface. Autapomorphies of SAM-PQMBD-81 Eustachian opening is wider and the antero-lateral shelf is better developed. SAM-PQMBD-81 has a rounded posterior end whereas IRSNB M 777 is pointed.

SAM-PQMBD-526 shares the following synapomorphies with 'Balaenoptera' borealina: pars 

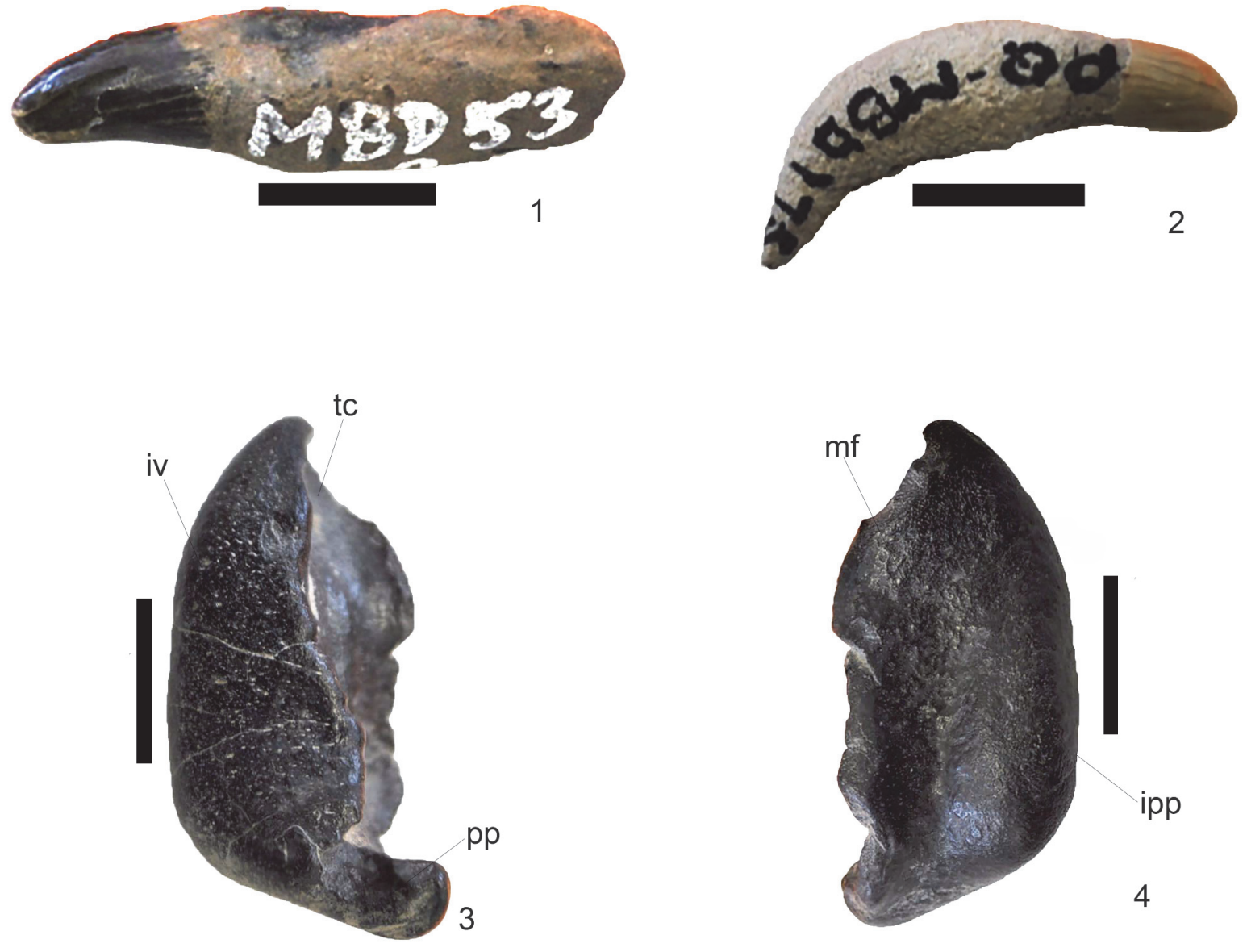

FIGURE 6. Isolated Odontoceti indet. teeth. 1) SAM-PQMBD-53A. 2) SAM-PQMBD-175. scale equals $0.5 \mathrm{~cm}$. Tympanic bulla of Odontoceti indet. (SAMPQMBD-1200). 3) medial view. 4) ventral view. scale equals $1 \mathrm{~cm}$.

cochlearis is short and wide; broad, trianglular anterior process; large, circular CNVIII; promontorial groove present.

Description. SAM-PQMBD-81 (Figure 2.1) is a relatively large tympanic bulla $(94.79 \mathrm{~mm})$ has a reniform shape and rounded anterodorsal corner typical of extinct and extant balaenopterids. The width of the tympanic bulla is $66.93 \%$ smaller than the length, it must be noted that the bone incomplete laterally. The tall and triangular conical process (Figure 2.1) is like 'Balaenoptera'. borealina, 'Balaenoptera' musculoides, cf. Plesiobalaenoptera, Incakujira and Plesiobalaenoptera and is taller than Parietobalaena, Pelocetus and Uranocetus. The involucral ridge is retracted from the ventral margin as seen in ' $B$.' borealina, ' $B$.' musculoides, Incakujira, Parietobalaena, Diorocetus, Pelocetus, Thinocetus, cf. Plesiobalaenoptera, Plesiobalaenoptera and extant balaenopterids (Figure 2.2). The main ridge forms a ventral keel (Figure 2.2) as seen in ' $B$.' borealina. The anteroventral corner is angular like Balaenoptera mysticetes,
Balaenoptera omurai, Balaenoptera musculus and Balaenoptera physalus, cf. Plesiobalaenoptera, Plesiobalaenoptera, Parietobalaena, 'B.' borealina, ' $B$.' musculoides and Pelocetus. It differs from other extant balaenopterids and Incakujira, which have a rounded anteroventral corner. The Eustachian opening is wide and ovoid which as in ' $B$.' borealina, 'B.' musculoides, B. musculus, B. omurai, B. physalus, Incakujira, and Parietobalaena (more basal for this character, Bosselaers, personal commun., 2017). The posterior end is wider than the anterior end and is angled to the rest of the bone similar to ' $B$.' borealina, cf. Plesiobalaenoptera, Plesiobalaenoptera, Incakujira, Pelocetus, Parietobalaena, Uranocetus and Megaptera. The involucrum surface is slightly concave like ' $B$.' borealina, Balaenoptera borealis, B. musculus, Megaptera, SAM-PQL-21230, Parietobalaena and Incakujira. In dorsal view, the anterolateral shelf is moderately well developed.

The periotic of SAM-PQMBD-526 is similar to extant balaenopterids, 'Balaenoptera' borealina, cf. 

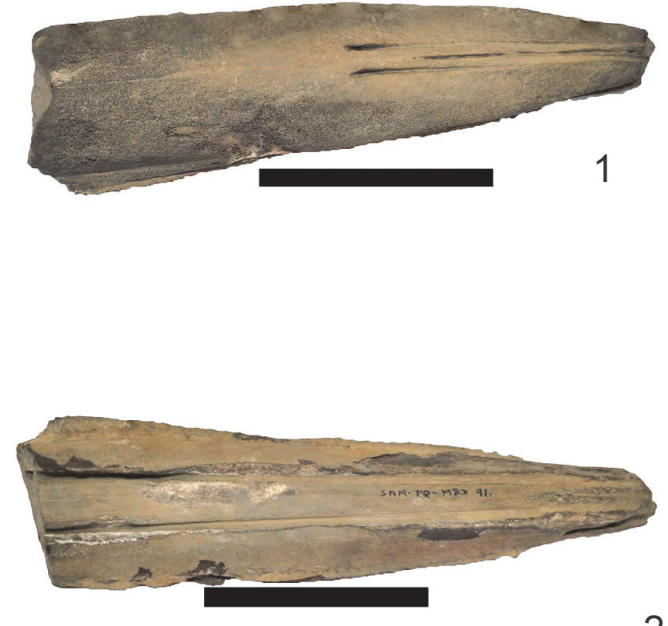

2

FIGURE 7. Rostral end of beaked whale skull cf Izikoziphius (SAM-PQMBD-91). 1) Ventral view. 2) Dorsal view. scale equals $10 \mathrm{~cm}$.

Plesiobalaenoptera and Plesiobalaenoptera in that the pars cochlearis (promontorium) is expanded (Figure 3.9-12; Table 3). The anterior process is a broad triangle (Figure 3.9) like ' $B$.' borealina, cf. Plesiobalaenoptera, Plesiobalaenoptera and the extant balaenopterids but differs from Diunatans, Fragilicetus, Balaenoptera acutorostrata, Balaenoptera edeni, Balaenoptera musculus, Balaenoptera omurai and Balaenoptera physalus where the anterior process is narrower. The pars cochlearis is similar to Balaenoptera acutorostrata, 'B.' borealina (IRSNB M 775B), B. edeni but is shorter, wider and flatter than cf. Plesiobalaenoptera and Plesiobalaenoptera and differs from Diunatans, B. musculus, B. physalus, B. borealis and Megaptera novaeangliae which have a globular pars cochlearis, and Fragilicetus which has a flatter pars cochlearis. A promontorial groove present in SAMPQMBD-526 same as ' $B$.' borealina, Diunatans and Fragilicetus.

The very small flange of the lateral tuberosity is dorsventrally thick (Figure 3.9) similar to Diunatans, Fragilicetus, Balaenoptera bonaerensis, Balaenoptera edeni and Balaenoptera acutorostrata but differs from ' $B$.' borealina, $B$. borealis, $B$. musculus, $B$. physalus and Megaptera novaeangliae which have a larger, better developed flange. Fenestra cochleae is separated from the perilymphatic foramen, which is similar to extant adult balaenopterids but differs from Eschrichtius robustus, some juvenile/foetal balaenopterids (Bisconti, 2001), B. borealis and in fossil balaenopterid taxa such as ' $B$. ' borealina, Fragilicetus, Diunatans, 'B.' sibbaldina and ' $B$.' musculoides, cf. Plesiobalaenoptera and Plesiobalaenoptera where they are confluent. There is a large, circular opening for CNVIII (IAM) and a small elliptical opening for CNVII (Figure 3.12) similar to 'B.' borealina, Diunatans. The IAM is separated from the CN VII opening by a relatively thick crista transversa as in ' $B$.' borealina, Diunatans, cf. Plesiobalaenoptera and Plesiobalaenoptera.

\section{BALAENOPTERIDAE Gray, 1864}

FRAGILICETUS Bisconti and Bosselaers, 2016 Fragilicetus $\mathrm{sp}$.

Figure 3.1-4

Referred material. SAM-PQMBD-49 -a weathered and incomplete right periotic lacking the posterior process (Figure 3.1-4; Table 3).

Locality and horizon. SAM-PQMBD-49 -Koeberg (Duinefontein), Duinefontein A, Power station, pump station, $-8.5 \mathrm{~m}$ (bsl).

Age. Zanclean (early Pliocene).

Diagnosis. Synapomorphies shared with Fragilicetus: well-developed embayment between the anterior process; promontorial groove, opening for $\mathrm{CN}$ VIII (IAM) is circular; crista transversa is broad and slightly recessed. Autapomorphies: elongated, inflated pars cochlearis; narrow triangular anterior process directed anteriorly.

Description. The narrow triangular anterior process (SAM-PQMBD -49) (Figure 3.1-4; Table 3) differs from Diunatans and Fragilicetus, which have an isosceles triangle anterior process, and cf. Plesiobalaenoptera (SAM-PQL-20482, SAM-PQL55001 and SAM-PQL-21230) and Plesiobalaenoptera and 'Balaenoptera' borealina where it is wider and shorter. Balaenoptera borealis has a wider and more angled anterior process. Pars cochlearis is inflated towards the distal end (cochlear foramen) and is longer anteroposteriorly $(37.11 \mathrm{~mm})$ than transversely $(23.37 \mathrm{~mm})$ giving it an elongated appearance (Figure 3.1-4), which differs from the broadly expanded one seen in Fragilicetus, 'Balaenoptera' borealina, cf. Plesiobalaenoptera, Plesiobalaenoptera, Diunatans and the extant balaenopterids. A promontorial groove is present similar to ' $B$.' borealina, Diunatans and Fragilicetus. Well-developed embayment between the pars cochlearis and anterior process (Figure 3.1) like Fragilicetus, Balaenoptera musculus and Balaenoptera physalus. Differs from the 'B.' borealina, cf. Plesiobalaenoptera, Plesiobalaenoptera, Diunatans and the remaining extant balaenopterids where the pars cochlearis is continuous with the anterior process (age (ontogeny) related, Bosse- 
TABLE 2. Measurements of the incomplete tympanic bullae from Duinefontein (Koeberg).

\begin{tabular}{lccccc}
\hline \multicolumn{1}{c}{ Specimen number } & SAM-PQMBD-81 & SAM-PQMBD-50 & SAM-PQMBD-80 & SAM-PQMBD-48 & SAM-PQMBD-1200 \\
\hline Total length $(\mathrm{mm})$ & 94.79 & 94.52 & 76.80 & 81.73 & 30.43 \\
Width $(\mathrm{mm})$ & 63.45 (posterior end) & 36.76 (incomplete) & 41.52 & 39.66 (incomplete) & 12.68 (incomplete) \\
Involucrum width (mm) & 33.51 & 36.44 & 2803 & 39.39 & 10.0 \\
Greatest depth (mm) & 47.0 & 48.0 & 35.0 & 34.0 & 4.0 \\
\hline
\end{tabular}

TABLE 3. Measurements of the isolated petrosals from Duinefontein (Koeberg).

\begin{tabular}{lcccc}
\hline \multicolumn{1}{c}{ Specimen number } & SAM-PQMBD-526 & SAM-PQMBD-49 & SAM-PQMBD-95 & SAM-MBD-363 \\
\hline Length $(\mathrm{mm})$ & 76.29 & 71.97 & 66.16 & 17.79 \\
Width $(\mathrm{mm})$ & 79.26 & 52.18 & 35.65 & 24.71 \\
$\begin{array}{l}\text { Pars cochlearis length } \\
(\mathrm{mm})\end{array}$ & 63.57 & 37.11 & 29.12 & 14.0 \\
$\begin{array}{l}\text { Pars cochlearis width } \\
(\mathrm{mm})\end{array}$ & 40.02 & $23 . .37$ & 20.95 & 12.0 \\
$\begin{array}{l}\text { Transverse width anterior } \\
\text { process }(\mathrm{mm})\end{array}$ & 41.42 & 17.19 & 33.64 & 8.0 \\
\hline
\end{tabular}

laers, personal commun., 2017). The small flange on the lateral tuberosity (Figure 3.1 ) is similar to Fragilicetus but smaller than Diunatans, 'B.' borealina, Balaenoptera borealis, Balaenoptera acutorostrata, Balaenoptera omurai and Balaenoptera physalis.

No suprameatal fossa (Figure 3.2) as in Balaenoptera borealis, Balaenoptera bonaerensis, Balaenoptera physalis, Balaenoptera omurai, Balaenoptera musculus, Balaenoptera edeni and Megaptera, while cf. Plesiobalaenoptera and Balaenoptera acutorostrata have a distinct suprameatal fossa. The opening for CN VIII (IAM) is circular, similar to Diunatans, 'B.' borealina, Fragilicetus, cf. Plesiobalaenoptera and Plesiobalaenoptera and that of CN VII is damaged (possible boring damage). The cochlear fenenstra is confluent with the perilymphatic foramen, similar to Eschrichtius robustus, some juvenile/foetal balaenopterids (Bisconti 2001), B. borealis and in fossil balaenopterid taxa such as ' $B$.' sibbaldina and 'B.' musculoides, Diunatans, Fragilicetus, 'B.' borealina, cf. Plesiobalaenoptera and Plesiobalaenoptera, but differs from extant adult balaenopterids.

BALAENOPTERIDAE Gray, 1864

DIUNATANS Bosselaers and Post 2010

Diunatans sp. 1

Figure 3.5-8

Referred specimen. SAM-PQMBD-95 - right periotic that is abraded with a damaged surface (Figure 3.5-8; Table 3).
Locality and horizon. SAM-PQMBD-95 - Duinefontein construction site.

Age. Zanclean (early Pliocene).

Diagnosis. Synapomorphies shared with Diunatans: an isosceles triangular anterior process; pars cochlearis has a short contact with the anterior process; a bulbous pars cochlearis; a small flange on the lateral tuberosity; a large circular CNVIII; the CNVIII separated from CN VII by a thick crista transversa.

Autapomorphies: SAM-PQMBD-95 is smaller (5 $\mathrm{cm}$ vs $10 \mathrm{~cm}$ ); the bulbous pars cochlearis is higher and narrower (20.95 $\mathrm{mm}$ vs $47 \mathrm{~mm}$ [holotype] and $39 \mathrm{~mm}$ [paratype]); L/W ratio 1.39 vs 1.23-1.26; fenestra cochleae is separate from the perilymphatic foramen.

Description. The anterior process of SAMPQMBD-95 (Figure 3.5; Table 3) forms an isosceles triangle like that of Diunatans, Balaenoptera acutorostrata and Balaenoptera borealis. It has a bulbous pars cochlearis (Figure 3.5) similar to Diunatans, Parietobalaena, Balaenoptera musculus, Balaenoptera phsalus Balaenoptera borealis and Megaptera novaeangliae and differs from the broadly expanded one seen in cf. Plesiobalaenoptera, Plesiobalaenoptera, Pelocetus, Uranocetus, Megaptera miocaena and the remaining extant balaenopterids. The L/W ratio of the pars cochlearis is 1.39 which greater than Diunatans luctoretemergo which ranges from 1.23-1.26. The pars cochlearis has a short contact with the anterior process as seen in cf. Plesiobalaenoptera, Plesiobalaenoptera, Diunatans, Uranocetus and the 
remaining extant balaenopterids. The small flange on the lateral tuberosity (Figure 3.5) is similar to Diunatans and $B$. acutorostrata but smaller than $B$. borealis, B.omurai and B. physalis.

Fenestra cochleae is separated from the perilymphatic foramen similar to adult balaenopterids and M. miocaena but differs from Eschrichtius robustus, some juvenile/foetal balaenopterids (Bisconti, 2001), B. borealis and in fossil balaenopterid taxa such as Diunatans, 'B.' borealina, cf. Plesiobalaenoptera, Plesiobalaenoptera, 'B.' sibbaldina and ' $B$.' musculoides where the perilymphatic foramen is confluent with the fenestra cochleae. The CNVIII (IAM) opening is circular, similar to Diunatans, cf. Plesiobalaenoptera and Plesiobalaenoptera.

\section{BALAENOPTERIDAE indet.}

Figure 4.1-12

Referred specimens. SAM-PQMBD-80 - right tympanic bulla is incomplete laterally with the conical and sigmoid processes missing (Figure 4.1-4; Table 2). SAM-PQMBD-50 - an incomplete right tympanic bulla (Figure 4.5-8; Table 2). SAMPQMBD-48 - a right tympanic bulla that is incomplete posteriorly and laterally (Figure 4.9-12; Table 2 ). It is broken posteriorly and the lateral surface is incomplete.

Locality and horizon. SAM-PQMBD-80 is from Duinefontein, Koeberg A, Power station, pickups reactor site, $-8.2 \mathrm{~m}--8.5 \mathrm{~m}$ below sea level (bsl). SAM-PQMBD-50 and SAM-PQMBD-48 are from Duinefontein, Koeberg A, Power station, pump station, $-8.5 \mathrm{~m}$ below sea level (bsl).

Age. Zanclean (early Pliocene).

Diagnosis. SAM-PQMBD-50 and SAM-PQ-MBD48 synapomorphies shared with extant and extinct balaenopterids: tympanic bulla is reniform shaped; longitudinal furrow towards the ventral border of the lateral surface; and planar involucrum surface. The involucral ridge of SAM-PQMBD-50 is retracted from the posterior end similar to the balaenids, Balaenoptera bonaerensis, Balaenoptera borealis, Balaenoptera musculus, Balaenoptera physalus, Eschrichtius robustus and Megaptera novaeangliae. The anteroventral corner of SAM-PQMBD-48 is angular similar to that of Balaenoptera omurai and Balaenoptera musculus.

SAM-PQMBD-80 synapomorphies shared with extinct and extant balaenopterids: reniform tympanic bulla; planar involucrum surface; involucrum is retracted from the ventral margin. SAMPQMBD-80 is similar to ' $B$.' borealina, ' $B$.' musculoides, cf. Plesiobalaenoptera, B. omurai and $B$. musculus as it has angular anteroventral corner.
There is a weakly developed longitudinal furrow along the ventral margin of the lateral surface similar to $B$. musculus, $B$. physalus and $B$. omurai.

Description. SAM-PQMBD-80 (Figure 4.1-4), SAM-PQMBD-50 (Figure 4.5-8) and SAMPQMBD-48 (Figure 4.9-12) tympanic bullae like fossil and extant balaenopterids are reniform shaped. Longitudinal furrow along the medial margin of the ventral surface of SAM-PQMBD-80 (Figure 4.2) and SAM-PQMBD-48 (Figure 4.9) similar to $B$. musculus, $B$. physalus and $B$. omurai. Longitudinal furrow midway on SAM-PQMBD-50 (Figure 4.5) similar to Eubalaena, B. musculus, B. physalus, $B$. oumrai and $B$. edeni.

Involucral ridge is retracted from the ventral margin in SAM-PQMBD-80, SAM-PQMBD-50 and SAM-PQMBD-48 as seen 'B.' borealina, 'B.' musculoides, Incakujira, Parietobalaena, Diorocetus, Pelocetus, Thinocetus, cf. Plesiobalaenoptera, Plesiobalaenoptera and extant balaenopterids. The ventral margin of SAM-PQMBD-50 is thickened similar to Incakujira. SAM-PQMBD-80 and SAMPQMBD-48 have angular anterodorsal corner similar to 'B.' borealina, ' $B$.' musculoides, Diunatans, $B$. mysticetes, B. omurai, B. musculus and B. physalus, cf. Plesiobalaenoptera, Plesiobalaenoptera, Pareitobalaena and Pelocetus. SAM-PQMBD-50, other extant balaenopterids, Incakujira have a rounded anteroventral corner.

The main ridge is parallel to the involucral ridge in SAM-PQMBD-80 and SAM-PQMBD-50 (Figure 4.3, 4.7) similar to 'B.' borealina, 'B.' musculoides, B. borealis and cf. Plesiobalaenoptera. In SAM-PQMBD-80 both ridges are narrow, prominent and have a curved appearance while in SAMPQMBD-50 the prominent main ridge is narrow becoming broad and flat posteriorly (Figure 4.7). The main ridge of SAM-PQMBD-48 (Figure 4.11) is relatively wide and slightly mediolaterally flattened and extends to the anterior end while the involucral ridge narrows in an anterior direction. In all three specimens, they merge at the anterior end while they are retracted from the posterior end, as in the balaenids, $B$. bonaerensis, B. borealis, B. musculus, B. physalus, Eschrichtius robustus and Megaptera novaeangliae. Differs from in ' $B$.' borealina, 'Balaenoptera' musculoides and cf. Plesiobalaenoptera where the involucral ridge reaches the distal end. Involucrum surface of SAM-PQMBD-81, SAM-PQMBD-50 and SAM-PQMBD-48 are planar as seen in B. omurai, B. physalus, B. edeni and SAM-PQL-55001 (cf. Plesiobalaenoptera taxon from Langebaanweg). 
PHOCOENIDAE Gray, 1825

cf. Australithax Muizon 1988a

Figure 5.1-3

Referred specimen. SAM-PQMBD-363 - left periotic is very small with the anterior and posterior processes preserved (Figure 5; Table 3).

Locality and horizon. Duinefontein, Koeberg A, Reactor site dumps.

Age. Zanclean (early Pliocene).

Diagnosis. Synapomorphies shared with Australithax: sinusoidal outline; anteriorly directed pars cochlearis; similar posterior process with threesided concave articulating surface that is directed posterolaterally; fossa capitis mallei similar shape but is larger in Australithax; ventral opening of the Fallopian aqueduct is similarly recessed. Autapomorphies: anterior process is larger, antero-medially directed and bifid dorsoventral tip, Australithax - groove between the cochlear fenestra and groove for the stapedial muscle.

Description. SAM-PQMBD-363 has a sinusoidal outline similar to Piscolithax tedfordi, Piscolithax boreios, Piscolithax longirostris, Australithax, Globicephalinae and kentriodontids. It has a large anterior and posterior processes like Piscolithax tedfordi and Piscolithax boreios but is larger than Piscolithax longirostris. It has a large posterior process like Australithax but Australithax has a smaller and short anterior process. It is more sinusoidal than Lomacetus but has a similarly large anterior process. The anterior process of SAMPQMBD-363 is (Figure 5.1) similar to Piscolithax tedfordi and Piscolithax boreios but differs from Lomacetus which does not have a bifid tip. The anterior process of Piscolithax longirostris is wider and shorter while the anterior process of Australithax is shorter and narrower. Pterophocaena and Phocoena also have a square and flat anterior process whereas Numataphocoena is semi-circular with a concave surface and Haborophocoena is a wide oval. The anterior process of Australithax is smaller than SAM-PQMBD-363 and is not bifid. The groove for CNVII (stapedial muscle) is similarly wide in Pterophocaena and Phocoena, Piscolithax tedfordi, Piscolithax boreios and Australithax but is wider than Numataphocoena, Semirostrum, Haborophocoena and Phocoena. It is narrower than Piscolithax longirostris.

The pars cochlearis (promontorium) is globular and angled towards the anterior process similar to Piscolithax tedfordi and Australithax, and more than Lomacetus but less than Piscolithax boreios and Piscolithax longirostris. It differs from Globicephalinae, which has a globular pars cochlearis and not angled. Although it is directed anteriorly it is more globular in Pterophocaena, Phocoena, Numataphocoena, Haborophocoena and Semirostrum. The anterior incisure is narrow in SAM-PQMBD-363, Piscolithax tedfordi, Piscolithax longirostris, Piscolithax boreios, Haborophocoena, Semirostrum and Phocoena while it is wider in Australithax, Numataphocoena and Pterophocaena. Fenestra rotunda is positioned higher up on pars cochlearis of Australithax and faces more ventrally than SAM-PQMBD-363. Australithax has an uneven pars cochlearis surface. Distance between the ventral opening of the Fallopian aqueduct and posterior process is smaller in SAMPQMBD-363.

The internal acoustic meatus (IAM) is large in SAM-PQMBD-363, Lomacetus, Australithax, Piscolithax longirostris, Piscolithax tedfordi and Piscolithax boreios but it is circular in Lomacetus and SAM-PQMBD-363 and takes up more of the cerebral surface (Figure 4.2) while it is elliptical in Pterophocaena, Phocoena, Numataphocoena, Haborophocoena and Semirostrum. Aqaeductus vestibuli is found in a depression in SAM-PQMBD363, Australithax, Lomacetus, Piscolithax tedfordi and Piscolithax boreios. The posterior process of SAM-PQMBD-363 is directed ventrally and has a concave three-sided articulating facet that is directed posterolaterally similar to Australithax, Piscolithax longirostris, Piscolithax tedfordi, Piscolithax boreios and Lomacetus. The mallear fossa is oval and shallow compared with Piscolithax tedfordi and Piscolithax boreios but similar to Lomacetus.

\section{ODONTOCETI INDET.}

Figure 6.1-4

Referred specimen. SAM-PQMBD-53A - complete tooth with an incomplete root and damaged enamel (Figure 6.1). SAM-PQMBD-175 - single complete tooth (Figure 6.2). SAM-PQMBD-1200 is part of the right tympanic bulla (Figure 6.3-4).

Locality and horizon. Duinefontein, Koeberg $A$, Power station, pump station -8.5 m. SAM-PQMBD175 - Duinefontein, Koeberg A, Reactor site dumps. SAM-PQMBD-1200 - Duinefontein, Koeberg.

Age. Zanclean (early Pliocene).

Diagnosis. SAM-PQMBD-53A synapomorphies shared with delphinids with short conical crown that is slightly recurved. Below the crown there is a shallow groove just about the proximal root typical of the Delphinoidea. SAM-PQMBD-175 has peglike appearance like delphinids. The crown is short and has the same width along its length. SAM- 
PQMBD-1200 has a total length of $30.43 \mathrm{~mm}$, which is within the range of delphininae (Kasuya, 1973); presence of median furrow considered plesiomorphic character (Kasuya, 1973). These specimens are therefore referred to Odontoceti indet.

Description. The crown of SAM-PQMBD-53A is short, conical and slightly recurved with a worn tip (Figure 6.1). Below the crown there is a shallow groove just about the proximal root. The root is thick near the crown and tapers distally where it is damaged. SAM-PQMBD-53A has an anteroposteriorly compressed root and crown. The crown of SAM-PQMBD-53A has a conical shape, curves slightly lingually and has no accessory cusps.

This single complete delphinid tooth (SAMPQMBD-175) has a slight chip on the enamel (Figure 6.2). The complete root is wide proximally and tapers to a point distally. The slightly curved crown is short and broad with a rounded tip. It is positioned at an angle to the root. The labial surface is convex, and the lingual surface is concave. It has a peg-like appearance.

SAM-PQMBD-1200 is a small tympanic bulla (30.43 mm). The involucrum is flat (Figure 6.3-4). The facet for the posterior process is narrower and small. SAM-PQMBD-1200 has a narrow inner posterior prominence (Figure 6.4).

\section{ODONTOCETI Flower, 1867 \\ ZIPHIIDAE Gray, 1850 \\ cf. IZIKOZIPHIUS Bianucci, Lambert, Post 2007 \\ Figure 7.1-2}

Referred specimen. SAM-PQMBD-91 - is the rostral part of the skull of a beaked whale skull (Figure 7).

Locality and horizon. Duinefontein construction site.

Age. Zanclean (early Pliocene).

Diagnosis. The maxilla flares laterally in a similar position in Izikoziphius; vomer fills the mesorostral groove and is flanked by shallow lateral grooves; vomer decreases in height rostrally; alveolar groove is present but is deeper in SAM-PQMBD91; mesolateral groove is filled with the vomer; wide rostrum; higher than wide towards the posterior end (identification confirmed by $\mathrm{O}$. Lambert, personal commun., 2017).

Description. The rostral end of a beaked whale skull shows damage due to weathering and is broken posteriorly. The fragmentary rostrum is elongated and narrows rostrally (Figure 7.1). On the dorsal surface below the ridge there is a groove that becomes deeper rostrally (Figure 7.1). There are diagonal sulci in the groove. Posteriorly the groove becomes narrow until it forms a ledge of lat- erally projecting bone. The premaxilla is formed by two unfused parts rostrally (Figure 7.1). They are flanked by the alveolar sulcus on either side that become deeper posteriorly and end as foramina on each side. At the posterior end there is a triangular, rugose slightly raised vomer.

Premaxillae and vomer are the best preserved (Figure 7.2). The skull narrows in the rostral direction with the tip broken off. Ventrally the vomer extends to the rostral end with a sulcus on either side. There is evidence of fusing of the vomer rostrally (Figure 7.2). The premaxilla forms a thin ridge in dorsal view and the steep sides reach a ridge in the middle. The surface of the ridge is rugose. Laterally, there is a thin ridge formed by the premaxillae which extend further laterally in a posterior direction to the level of the posterior end of the foramina. Above this there are grooves. The lateral surface of the bone is flattened towards the rostral end.

\section{DISCUSSION}

\section{Comparison with Other Early Pliocene Cetacean Assemblages}

The marine mammal fossils from South Africa's west coast are being studied to reconstruct the Mio-Pliocene marine palaeoenvironment along the west coast and to understand the faunal changes that have occurred over the past $5 \mathrm{Ma}$. Three balaenopterids (cf. Plesiobalaenoptera) have been described from Langebaanweg, and an unidentified odontocete is present while three balaeonpterids ('Balaenoptera' borealina, Diunatans sp. 1, Fragilicetus sp.), one porpoise (cf. Autralithax), one beaked whale cranial fragment (cf. Izikoziphius), unidentified balaenopterids and possible delphinids have been described from Koeberg. These belong to extinct taxa. There were 10 new Langhian-Messinian (mid-late Miocene) beaked whale species described from trawled material off the west coast of South Africa (Bianucci et al., 2007, 2008). During the late Miocene - early Pliocene (Messinian - Zanclean) along the southwestern Cape coast there were six mysticete taxa compared with seven present in the region today while there are 28 odontocetes living on the coast (Findlay et al., 1992; Best, 2007) while in the past there were potentially only five odontocetes living along the coast. Only one phocoenid has lived off the coast at $5 \mathrm{Ma}$ and at present (Best, 2007).

When compared with Pliocene marine mammal localities the cetaceans along the southwest- 
ern coast of South Africa all belong to extinct taxa unlike those in the Yorktown Formation (odontocetes - modern in their makeup, eight delphinids, three ziphiids and no porpoises), Australia and New Zealand (have balaenids, six balaenopterids, three delphinids and a sperm whale) including extant taxa (Boessenecker, 2013; Fitzgerald, 2004, 2005). The eastern North Pacific cetacean fauna is mostly extinct (12 mysticetes including a gray whale and balaenids, two to three sperm whales and a number of porpoises) but there are also some extant taxa (Boessenecker, 2013). The south-western Cape shares the following cetaceans with North Atlantic localities of a similar age; cf. Plesiobalaenoptera with Italy (three balaenids, few porpoises, four balaenopterids and delphinds and early gray whale Eschrichtioides) (Boessenecker, 2013; Bisconti, 2008), Diunatans, Fragilicetus and ' $B$.' borealina with Belgium and the Netherlands (a number of balaenopterids, three balaenids, one porpoise, two delphinids and three ziphiids) as well as ' $B$.' borealina with the Yorktown Formation (Whitmore and Kaltenbach, 2008; Boesselaer and Post, 2010; Boessenecker, 2013; Bisconti and Bosselaer, 2016). The southwestern Cape has remains of a porpoise (cf. Australithax) similar to the Pisco Formation, eastern South Pacific, (diverse fauna - odontocete, one sperm whale, two phocoenids, one ziphiid, several mysticetes, one cetothere, two sperm whales, two delphinine delphinids, globicephaline delphinids, one pontoporiid and indeterminate monodontid). They were collected as isolated elements in the Pisco Formation (Lambert, personal commun., 2017). The Yorktown Formation (North Atlantic), Australia and New Zealand (South Pacific) differ from South Africa's south-western coast in that no porpoises have been described (Boessenecker, 2013). Herpetocetus has also not been described from Italy (Boessenecker, 2013) or South Africa. The beaked whale fauna off South Africa's south and southwestern coasts was very diverse during the MioPliocene and included at least 10 species (Bianucci et al., 2007, 2008) similar to today with at least nine ziphiid species that are resident or visit South African waters (Bianucci et al., 2008). South Africa has a higher beaked whale diversity during the Mio-Pliocene compared with other similar aged sites. No cetotheriid, balaenids or gray whale have been described from the South African west coast to date.

South Africa is only the second occurrence of the Diunatans, represented by a smaller species, and Fragilicetus which link the fauna of the south- western Cape with the North Sea while the presence of ' $B$.' borealina links with the eastern and western North Atlantic. Australithax (porpoise) suggests a link to the eastern South Pacific.

\section{Palaeoenvironment and Biogeography}

Although upwelling is indicated from about 15 Ma, establishment of the Benguela Upwelling System (BUS) was marked by the change to cold water dominant nanoplankton in the late Miocene (7.2 Ma)-early Pliocene on the northern Namibian coast (Siesser, 1980). Decrease in the sea surface temperature and ambient temperature in the early Pliocene on the southern African coast and increased nutrient production of the BUS were key factors influencing biotas of the period (Tankard and Rogers, 1978; Siesser, 1980; Siesser and Dingle, 1981). Large phytoplankton populations are produced by the cold nutrient-rich water that results from the surface water being removed offshore by the Coriolis effect on the prevailing summer south east wind, making this the world's richest fishing ground (Ansorge and Lutjeharms, 2007; Rommerskirchen et al., 2011). Increased productivity in the Cape Basin from 6.7-6.5 Ma matched similar documented changes in equatorial and northeast Pacific and equatorial Indian Oceans between 6.9 Ma and 6.5 Ma (Diester-Haass et al., 2002).

Higher sea levels created islands off South Africa's west coast during the Zanclean (5 Ma) (Hendey, 1981; Erasmus, 2005; Roberts et al., 2006); areas of high relief, particularly in the vicinity of Langebaanweg, formed an archipelago of granite islands in a shallow sea channel that separated St. Helena Bay and Saldanha Bay, while other islands are indicated by the presence of aluminium phosphate (leached from bird guano) in the Saldanha and Posberg Peninsula (Hendey, 1981; Hendey and Dingle, 1989; Erasmus, 2005; Roberts et al., 2011). The Cape Flats was also inundated at this time, linking False and Table Bays and forming islands off Table Mountain and other peaks off the Cape peninsula (Olson, 1983). Duinefontein (Koeberg) was open to the ocean from time to time but during deposition a barrier spit formed a lagoon in the area (Rogers, 1979).

A number of small oceanic islands make up the sub-Antarctic region (Briggs, 2003). Kespka et al. (2006) identified Australia/New Zealand (outside the Antarctic convergence) as ancestral habitats for the penguin clade, followed by South America and the Antarctic peninsula. During the Miocene and Pliocene four species of penguins are 
known from South Africa like the Falkland Islands today where there are five breeding penguin species (Thomas and Ksepka, 2013). A high sympatric penguin diversity in the South Atlantic is implied by the large number of penguin species in the MioPliocene of South Africa and the Falkland Island today (Thomas and Ksepka, 2013).

During the transgressive phases in the late Miocene and early Pliocene the Strait of Gibraltar was flooded (Hendey and Dingle, 1989; Potter and Szatmari, 2009). The Strait of Gibraltar is considered an important link that allowed marine mammals access to the Atlantic Ocean and later after the Messinian Salinity Crisis allowed marine mammals to recolonise the Mediterranean (Peredo and Uhen, 2016). This would have provided an ideal passageway to allow the cf. Plesiobalaenoptera taxa to move into the southern Atlantic. The North Sea basin was also linked to the Atlantic Ocean in the Pliocene (Lambert and Gigase, 2007). This connection between the oceans would have allowed cetaceans to move between basins and oceans. This could have seen Diunatans, Fragilicetus and 'B.' borealina being able to migrate between the north and south Atlantic basins and oceans. The Diunatans specimen from the west coast of South Africa may represent a new species, which can only be confirmed once more material is found.

The dispersal of "southern otariids" into the Southern Hemisphere from the North Pacific was related to the decrease in subtropical sea surface temperatures and an increase in equatorial productivity (Churchill et al., 2014). This dispersal took place between 6 and 7 Ma when there were unusually cool sea surface temperatures and high productivity in the eastern equatorial Pacific (Churchill et al., 2014). Inguza and/or Nucleornis penguin lineages dispersed from South America or AustroNew Zealand to intermediate oceanic islands and arrived in southern Africa in the early Pliocene (Ksepka and Thomas, 2011). The Antarctic Circumpolar current (ACC), which flows to the south of Africa, and the South Atlantic current (SAC) continue along the west coast of Africa as the Benguela Current, probably played a role in the dispersal of penguins to Africa (Ksepka and Thomas, 2011). The cetaceans from the Pacific could have followed a similar route during the early Pliocene to reach the west coast of South Africa. An alternate route during this time could have been through the Central American Seaway which still linked the Pacific with the Atlantic Oceans (Lambert and Gigase, 2007; Peredo and Uhen, 2016).
The increased nutrient production in the Benguela Upwelling System would have been able to support a varied cetacean population that most likely exploited different niches as suggested by the fossil cetaceans described from Langebaanweg and now Koeberg. The fossil cetacean taxa identified from Langebaanweg and Koeberg include at least six mysticetes with most of the odontocetes only identified to the family level and others remaining unidentified due to poor preservation; a single porpoise has been identified. The trawled fossil beaked whales suggest a very rich beaked whale community on the west and south coasts during the middle to late Miocene (Bianucci et al., 2007, 2008). The fossil and extant South African beaked whale faunas have a wide range of body sizes that may relate to different dietary niches and a wide use of the water column (Bianucci et al., 2007, 2008).

Extant right whale and humpback whales migrate between feeding areas and breeding grounds and have temporary residential groups that live off the west coast (Barendse et al., 2010, 2011). The area around Saldanha Bay/St Helena Bay is a summer feeding ground for humpback and southern right whales on the southwestern Cape coast (Barendse et al., 2010, 2011). With large lagoons or embayments present during the early Pliocene it is possible that cetaceans also exploited these feeding grounds year-round.

Pimiento et al. (2017) suggest that extinction and erosion of functional diversity was driven by sea level changes that resulted in habitat loss as well as oceanographic changes, changes in productivity and changes in circulation. The penguins experienced a reduction in diversity from the Pliocene to the Pleistocene (Thomas and Ksepka, 2013). This was most likely a result of the changes in sea level and restructuring of the marine community around the western Cape (Thomas and Ksepka, 2013). There is also a turnover in the marine avifauna, which are now present in the subAntarctic (Olson, 1983). Arctocephalus pusillus replaced Homiphoca capensis as the dominant seal on the South African coast. The Pleistocene regression led to the reduction in the number of islands, which would have provided haul-out sites by the phocid seals (Curtis et al., 2009). Fur seals replaced the phocid seals on the South Africa's west coast due to their ability to exploit shallow water (David, 1987). Presence of rocky and steeper beaches are more easily exploited by fur seals. This was contemporaneous with the 
replacement of phocids in South America (Valenzuela-Toro, 2013).

\section{CONCLUSION}

There was a varied cetacean community off the South African west coast five million years ago similar to the one seen today. Duinefontein (Koeberg) was open to the ocean and its wave action but a lagoon or large embayment formed once the barrier spit had developed, and this was when the fossils were deposited (Rogers, 1979). The balaenopterids present are 'B.' borealina, Diunatans sp. 1 and Fragilicetus sp. while other remaining specimens are considered indeterminate balaenopterids. Diunatans sp.1 most likely represents a new species but it can only be confirmed once more material is found. This second occurrence of the Diunatans, a smaller species and Fragilicetus link the fauna of the southwestern Cape with the North Sea while the presence of 'B.' borealina shows a link with the eastern and western North Atlantic. The presence of the porpoise Australithax suggests a link to the eastern South Pacific. These porpoises would have used the West Wind Drift or Central American seaway to gain access to the south Atlantic. The remaining odontocetes were only identified as Odontoceti indet. The cetaceans at Koeberg indicate connections to northeastern and north-western Atlantic, the Mediterranean, the southeastern north Pacific and southeastern southern Pacific, during the early Pliocene.

\section{ACKNOWLEDGEMENTS}

RG thanks the Cenozoic Palaeontology staff from Iziko South African Museum for their assistance. GA (as Curator Quaternary Palaeontology, Iziko Museums of South Africa) for organising the first visit to Koeberg and for assistance with arranging future visits to the site. EB (Iziko Museums of South Africa) for his assistance with compiling the stratigraphic section and RB (College of Charleston, Charleston) for helpful comments on the manuscript. DPO and NF (Iziko Museums of South Africa, Iziko South African Museum) for assistance with the extant marine mammal collections. This work is funded by NRF/AOP grant (grant no. 98834). The two anonymous reviewers are thanked for their comments, which have greatly enhanced this paper. RG thanks MB (Royal Belgian Institute of Natural Sciences and Koninklijk Zeeuwsch Genootschap der Wetenschappen, Middelburg, The Netherlands) for his discussions about the Koeberg material and comments on the latest revision and OL (Royal Belgian Institute of Natural Sciences) for his discussions about the odontocetes. RG thanks AF Curator Paleontology Collections for access to the cetacean fossils at Royal Belgian Institute of Natural Sciences. RG also thanks GA (Iziko Museums of South Africa) for comments on the latest revision and $\mathrm{DH}$ (Iziko Museums of South Africa) for comments on the initial draft.

\section{REFERENCES}

Ansorge, I.J. and Lutjeharms, J.R.E. 2007. The cetacean environment off southern Africa, p 513. In Best, P.B. (ed.), Whales and Dolphins of the Southern African Subregion. Cape Town: Cambridge University Press.

Avery, G. and Klein, R.G. 2011. Review of fossil phocid and otariid seals from the southern and western coasts of South Africa. Transactions of the Royal Society of South Africa, 66(1):1424. https://doi.org/10.1080/0035919X.2011.564490

Barendse, J., Best, P.B., Thornton, M., Elwen, S.H., Rosenbaum, H.C., Carvalho, I., Pomilla, C., Collins, T.J.Q., and Meyer, M. 2011. Transit station or destination? Attendance patterns, regional movement and population estimate of humpback whales off west South Africa from photographic and genotypic matching. In Kirkman, S.P., Elwen, S.H., Pistorius, P.A., Thornton, M., and Weir, C.R. (eds.), Conservation biology of marine mammals in the southern African subregion. African Journal of Marine Science, 33:353-373. https://doi.org/ 10.2989/1814232x.2011.637343

Barendse, J., Best, P.B., Thornton, M., Pomilla, C., Carvalho, I., and Rosenbaum, H.C. 2010. Migration redefined? Seasonality, movements and group composition of humpback whales Megaptera novaeangliae off the west coast of South Africa. African Journal of Marine Science, 32:1-22. https://doi.org/10.2989/18142321003714203 
Barnes, L.G. 1984. Fossil odontocetes (Mammalia: Cetacea) from the Almejas Formation, Isla Cedros, Mexico. PaleoBios, 42:1-46.

Best, P.B. 2007. Whales and Dolphins of the Southern African Subregion. Cambridge University Press, New York.

Bianucci, G., Lambert, O., and Post, K. 2007. A high diversity in fossil beaked whales (Mammalia, Odontoceti, Ziphiidae) recovered by trawling from the sea floor off South Africa. Geodiversitas, 29:561-618.

Bianucci, G., Post, K., and Lambert, O. 2008. Beaked whale mysteries revealed by seafloor fossils trawled off South Africa. South African Journal of Science, 104:140-142.

Bisconti, M. 2001. Morphology and postnatal growth trajectory of rorqual petrosal. Italian Journal of Zoology, 68:87-93. https://doi.org/10.1080/11250000109356390

Bisconti, M. 2008. Morphology and phylogenetic relationships of a new eschrichtiid genus (Cetacea: Mysticeti) from the early Pliocene of northern Italy. Zoological Journal of the Linnean Society, 153:161-186. https://doi.org/10.1111/j.1096-3642.2008.00374.x

Bisconti, M. 2010. A new balaenopterid whale from the late Miocene of the Stirone River, northern Italy (Mammalia, Cetacea, Mysticeti). Journal of Vertebrate Paleontology, 30:943958. https://doi.org/10.1080/02724631003762922

Bisconti, M. and Bosselaers, M. 2016. Fragilicetus velponi: a new mysticete genus and species and its implications for the origin of Balaenopteridae (Mammalia, Cetacea, Mysticeti). Zoological Journal of the Linnean Society, 177(2):450-474. https://doi.org/10.1111/zoj.12370

Boessenecker R.W. 2013. A new marine vertebrate assemblage from the Late Neogene Purisima Formation in Central California, part II: Pinnipeds and Cetaceans. Geodiversitas, 35(4):815-940. https://doi.org/10.5252/g2013n4a5

Boessenecker, R.W., Perry, F.A., and Schmitt, J.G. 2014. Comparative taphonomy, taphofacies, and bonebeds of the Mio-Pliocene Purisima Formation, Central California: Strong physical control on marine vertebrate preservation in shallow marine settings. PLoS One, 9(3):e91419. https://doi.org/10.1371/journal.pone.0091419

Boessenecker, R.W., Perry, F.A., and Geisler, J.H. 2015. Globicephaline whales from the MioPliocene Purisima Formation of central California, USA. Acta Palaeontologica Polonica, 60(1):13-122. https://doi.org/10.4202/app.2013.0019

Bosselaers, M. and Post, K. 2010. A new fossil rorqual (Mammalia, Cetacea, Balaenopteridae) from the Early Pliocene of the North Sea, with a review of the rorqual species described by Owen and Van Beneden. Geodiversitas, 32(2):331-363. https://doi.org/10.5252/g2010n2a6

Briggs, J.C. 2003. Marine centres of origin as evolutionary engines. Journal of Biogeography, 30:1-18. https://doi.org/10.1046/j.1365-2699.2003.00810.x

Churchill, M., Boessenecker, R.W., and Clementz, M.T. 2014. Colonization of the Southern Hemisphere by fur seals and sea lions (Carnivora: Otariidae) revealed by combined evidence phylogenetic and Bayesian biogeographical analysis. Zoological Journal of the Linnean Society, 172(1):200-225. https://doi.org/10.1111/zoj12163

Cione, A.L., Acosta Hospitaleche, C., Pérez, L.M., Laza, J.H., and César, I. 2010. Trace fossils on penguin bones from the Miocene of Chubut, southern Argentina. Alcheringa, 34(4):433454. https://doi.org/10.1080/03115511003793470

Curtis, C., Stewart, B.S., and Karl, S.A. 2009. Pleistocene population expansions of Antarctic seals. Molecular Ecology, 18(10):2112-2121. https://doi.org/10.1111/j.1365294X.2009.04166.x

David, J.H.M. 1987. South African Fur Seal, Arctocephalus pusillus pusillus, p.65-71. In Croxall, J.P. and Gentry, R.L (eds.), NOAA Technical Report NMFS 51, Proceedings of an International Symposium and Workshop on Biology and Ecology of Fur Seals. Cambridge, UK, 23-27 April 1984.

de Lacépède, B.G.E. 1804. Histoire naturelle des cétacées. In Buffon, Histoire Naturelle, 37:317.

de Muizon, C. 1988a. Les vertebres fossiles de la Formation Pisco (Perou). Troisieme partie: Les Odontocetes (Cetacea, Mammalia) du Miocene. Editions Recherche sur les Civilisations, Paris. (In French). https://doi.org/10.1016/s0016-6995(89)80106-8

de Muizon, C. 1988b. Les relations phylogenetiques des Delphinida (Cetacea, mammalia). In Annales de Paléontologie, 74(4):159-227. (In French)

Diester-Haass, L., Meyers, P.A., and Vidal, L. 2002. The late Miocene onset of high productivity in the Benguela Current upwelling system as part of a global pattern. Marine Geology, 180(1):87-103. https://doi.org/10.1016/s0025-3227(01)00207-9 
Dingle, R.V., Siesser, W.G., and Newton, A.R. 1983. Mesozoic and Tertiary Geology of Southern Africa. Rotterdam: A.A. Balkema.

Ekdale, E.G., Berta, A., and Deméré, T.A. 2011. The comparative osteology of the petrotympanic complex (ear region) of extant baleen whales (Cetacea: Mysticeti). PLoS ONE, 6, e21311. https://doi.org/10.1371/journal.pone.0021311

Erasmus, L. 2005. Virtual reconstruction of stratigraphy and past landscapes in the West Coast Fossil Park region. Unpublished MSc Thesis, University of Stellenbosch, South Africa. http:// hdl.handle.net/10019.1/2530

Findlay, K.P., Best, P.B., Ross, G.J.B., and Cockcroft, V.G. 1992. The distribution of small odontocete cetaceans off the coasts of South Africa and Namibia. South African Journal of Marine Science, 12(1):237-270. https://doi.org/10.2989/02577619209504706

Fitzgerald, E.M.G. 2004. A review of the Tertiary fossil Cetacea (Mammalia) localities in Australia. Memoirs of Museum Victoria, 61(2):183-208. https://doi.org/10.24199/ j.mmv.2004.61.12

Fitzgerald, E.M.G. 2005. Pliocene marine mammals from the Whalers Bluff Formation of Portland, Victoria, Australia. Memoirs of Museum Victoria, 62(1):67-89. https://doi.org/ 10.24199/j.mmv.2005.62.2

Flower, W.H. 1867. Description of the skeleton of Inia geoffrensis and the skull of Pontoporia blainvilli, with remarks on the systematic position of these animals in the order Cetacea. Transactions of the Zoological Society of London, 6:87-116.

Govender, R. 2015. Shark-cetacean trophic interaction at Duinefontein (Koeberg) (5 Ma), South African west coast. South African Journal of Science, 111(11/12):1-7. https://doi.org/ $10.17159 /$ sajs.2015/20140453

Govender, R., Bisconti, M., and Chinsamy, A. 2016. A late Miocene-early Pliocene baleen whale assemblage from Langebaanweg, west coast of South Africa (Mammalia, Cetacea, Mysticeti). Alcheringa, 40:542-555. https://doi.org/10.1080/03115518.2016.1159413

Gray, J.E. 1825. An outline of an attempt at the disposition of Mammalia into tribes and families, with a list of the genera apparently appertaining to each tribe. Philosophical Annals, 26:337344.

Gray, J.E. 1850. Catalogue of the specimens of Mammalia in the collections of the British Museum. Part I - Cetacea. London: Taylor R \& JE.

Gray, J.E. 1864. Notes on the Whalebone-Whales; with a synopsis of the species. The Annals and Magazine of Natural History, 14:345-353.

Gutstein, C.S., Figueroa-Bravo, C.P., Pyenson, N.D., Yury-Yañez, R.E., Cozzuol, M.A., and Canals, M. 2014. High frequency echolocation, ear morphology, and the marine-freshwater transition: A comparative study of extant and extinct toothed whales. Palaeogeography, Palaeoclimatology, Palaeoecology, 400:62-74. https://doi.org/10.1016/j.palaeo.2014.01.026

Hendey, Q.B. 1981. Palaeoecology of the Late Tertiary fossil occurrences in 'E' Quarry, Langebaanweg, South Africa, and a reinterpretation of their geological context. Annals of South African Museum, 84(1):1-104.

Hendey, Q.B. 1983. Cenozoic geology and palaeogeography of the fynbos region, p. 35-60. In Deacon, H.J., Hendey, Q.B., and Lambrechts, J.J.N. (eds.), Fynbos Palaeoecology: A Preliminary Synthesis. South African National Programmes Report 75.

Hendey, Q.B. and Dingle, R.V. 1989. Onshore sedimentary phosphate deposits in southwestern Africa, p. 200-206. In Notholt, A.J.G., Sheldon, R.P., and Davidson, D.F. (eds.), Phosphate Deposits of the World, vol. 2: Phosphate Rock Resources. Cambridge University Press, Cambridge.

Ichishima, H. and Kimura, M. 2000. A new fossil porpoise (Cetacea; Delphinoidea; Phocoenidae) from the Early Pliocene Horokaoshirarika Formation, Hokkaido, Japan. Journal of Vertebrate Paleontology, 20(3):561-576. https://doi.org/10.1671/02724634(2000)020[0561:ANFPCD]2.0.CO;2

Ichishima, H. and Kimura, M. 2005. Haborophocoena toyoshimai, a new early Pliocene porpoise (Cetacea; Phocoenidae) from Hokkaido, Japan. Journal of Vertebrate Paleontology, 25(3):655-664. https://doi.org/10.1671/0272-4634(2005)025[0655:HTANEP]2.0.CO;2

Kasuya, T. 1973. Systematic consideration of recent toothed whales based on the morphology of tympano-periotic bone. Scientific Reports of the Whales Research Institute, 25:1-103.

Kellogg, R. 1969a. Fossil Marine Mammals from the Miocene Calvert Formation of Maryland and Virginia, parts 1-8. Bulletin of the United States National Museum, 247:1-201. 
Kellogg, R. 1969b. Cetothere skeletons from the Miocene Choptank Formation of Maryland and Virginia. Bulletin of the United States National Museum, 294:1-24.

Ksepka, D.T., Bertelli, S., and Giannini, N.P. 2006. The phylogeny of the living and fossil Sphenisciformes (penguins). Cladistics, 22:412-441. https://doi.org/10.1111/j.10960031.2006.00116.x

Ksepka, D.T. and Thomas, D.B. 2011. Multiple Cenozoic invasions of Africa by penguins (Aves, Sphenisciformes). Proceedings of the Royal Society B, 279(1730):1027-1032. https://doi.org/ 10.1098/rspb.2011.1592

Lambert, O. and Gigase, P. 2007. A monodontid cetacean from the Early Pliocene of the North Sea. Bulletin van het Koninklijk Belgisch Instituut voor Natuurwetenschappen and Aardwetenschappen, 77:197-210.

Marx, F.G., and Kohno, N. 2016. A new Miocene baleen whale from the Peruvian desert. Royal Society Open Science, 3(10):160542. https://doi.org/10.1098/rsos.160542

Mead, J.G. and Fordyce, R.E. 2009. The therian skull: a lexicon with emphasis on the odontocetes. Smithsonian Contributions to Zoology, 1-249. https://doi.org/10.5479/ si.00810282.627

Murakami, M., Shimada, C., Hikida, Y., and Hirano, H. 2012. A new basal porpoise, Pterophocaena nishinoi (Cetacea, Odontoceti, Delphinoidea), from the upper Miocene of Japan and its phylogenetic relationships. Journal of Vertebrate Paleontology, 32(5):11571171. https://doi.org/10.1080/02724634.2012.677299

Olson, S.L. 1983. Fossil seabirds and changing marine environments in the Late Tertiary of South Africa. South African Journal of Science, 79(10):399-402.

Olson, S.L. 1985a. An early Pliocene marine avifauna from Duinefontein, Cape Province, South Africa. Annals of the South African Museum, 95(4):147-165.

Olson, S.L. 1985b. Early Pliocene Procellariiformes (Aves) from Langebaanweg, southwestern Cape Province, South Africa. Annals of the South African Museum, 95(3):123-145.

Peredo, C.M. and Uhen, M.D. 2016. Exploration of marine mammal paleogeography in the Northern Hemisphere over the Cenozoic using beta diversity. Palaeogeography, Palaeoclimatology, Palaeoecology, 449:227-235. https://doi.org/10.1016/ j.palaeo.2016.02.034

Pether, J., Roberts, D.L., and Ward, J.D. 2000. Deposits of the West Coast, p. 33-54. In Partridge, T.C. and Maud, R.R. (eds.), The Cenozoic of southern Africa. Oxford University Press, Oxford.

Pimiento, C., Griffin, J.N., Clements, C.F., Silvestro, D., Varela, S., Uhen, M.D., and Jaramillo, C. 2017. The Pliocene marine megafauna extinction and its impact on functional diversity. Nature ecology \& evolution, 1(8):1100-1106. https://doi.org/10.1038/s41559-017-0223-6

Potter, P.E. and Szatmari, P. 2009. Global Miocene tectonics and the modern world. EarthScience Review, 96:279-295. https://doi.org/10.1016/j.earscirev.2009.07.003

Racicot, R.A., Deméré, T.A, Beatty, B.L., and Boessenecker, R.W. 2014. Unique feeding morphology in a new prognathous extinct porpoise from the Pliocene of California. Current Biology, 24:774-779. https://doi.org/10.1016/j.cub.2014.02.031

Roberts, D.L. 2006. Lithostratigraphy of the Sandveld Group. South African Committee for Stratigraphy Lithostratigraphic Series, 9:25-26.

Roberts, D.L., Botha, G.A., Maud, R.R., and Pether, J. 2006. Coastal Cenozoic deposits, p. 605628. In Johnson, M.R., Anhaeusser, C.R., and Thomas, R.J. (eds.), The Geology of South Africa. Geological Society of South Africa, Johannesburg/Council for Geoscience, Pretoria.

Roberts, D.L., Matthews, T., Herries, A.I.R., Boulter, C., Scott, L., Dondo, C., Mtembi, P., Browning, C., Smith, R.M.H., Haarhoff, P., and Bateman, M.D. 2011. Regional and global context of the Late Cenozoic Langebaanweg (Langebaanweg) Palaeontological Site: West Coast of South Africa. Earth-Science Review 106:191-214. https://doi.org/10.1016/ j.earscirev.2011.02.002

Rogers, J. 1979. The sedimentary succession at the Koeberg nuclear power station, Melkbosstrand. 18th Congress of Geological Society of South Africa, 1979:310-322.

Rogers, J. 1980. First report on the Cenozoic sediments between Cape Town and Eland's Bay. Geological Survey of South Africa Open File 165. (unpublished).

Rogers, J. 1982. Lithostratigraphy of Cenozoic sediments between Cape Town and Eland's Bay. Palaeoecology of Africa, 15:121-137. 
Rogers, J. 2006. Sedimentology of Late Cenozoic sediments, including the Pliocene Dynefontyn Member of the Varswater Formation, Koeberg Nuclear Power Station, Melkbosstrand, Cape Town. African Natural History, 2:194-196. http://hdl.handle.net/10520/EJC17342

Rommerskirchen, F., Condon, T., Mollenhauer, G., Dupont, L., and Schefuß, E. 2011. Miocene to Pliocene development of surface and subsurface temperatures in the Benguela Current system. Paleoceanography, 26(3). https://doi.org/10.1029/2010pa002074

Siesser, W.G. 1980. Late Miocene Origin of the Benguela Upswelling System off Northern Namibia. Science, New series, 208(4441):283-285. https://doi.org/10.1126/ science.208.4441.283

Siesser, W.G. and Dingle, R.V. 1981. Tertiary Sea-Level movements around Southern Africa. Journal of Geology, 89(4):523-536. https://doi.org/10.1086/628618

Steeman, M.E. 2009. A new baleen whale from the Late Miocene of Denmark and early mysticete hearing. Palaeontology, 52(5):169-1190. https://doi.org/10.1111/j.14754983.2009.00893.x

Tankard, A.J. and Rogers, J. 1978. Late Cenozoic Palaeoenvironments on the West Coast of Southern Africa. Journal of Biogeography, 5(4):319-337. https://doi.org/10.2307/3038026

Thomas, D.B. and Ksepka, D.T. 2013. A history of shifting fortunes for African penguins. Zoological Journal of the Linnean Society, 168(1):207-219. https://doi.org/10.1111/zoj.12024

Valenzeula-Torro, A.M., Gutstein, C.S., Vara-Malca, R.M., Suarez, M.E., and Pyenson, N.D. 2013. Pinniped turnover in the South Pacific Ocean: new evidence from the Plio-Pleistocene of the Atacama Desert, Chile. Journal of Vertebrate Paleontology, 33(1):216-223. https:// doi.org/10.1080/02724634.2012.710282

Van Beneden, P.-J. 1880. Les mysticetes a court fanons des sables des environs d'Anvers. Bulletin Academy of Science Belgique, 50:11-27.

Van Beneden, P.-J. 1882. Description des ossements fossils des environs d' Anvers. Troisieme partie. Cétacés, genres Megaptera, Balaenoptera, Burtinopsis, et Erpetocetus. Annales du Musee Royal d'Histoire Naturelle de Belgique, 7:1-90.

Whitmore, Jr, F.C. and Kaltenbach, J.A. 2008. Neogene Cetacea of the Lee Creek Phosphate Mine, North Carolina. Virginia Museum of Natural History Special Publication, 14:181-269. 